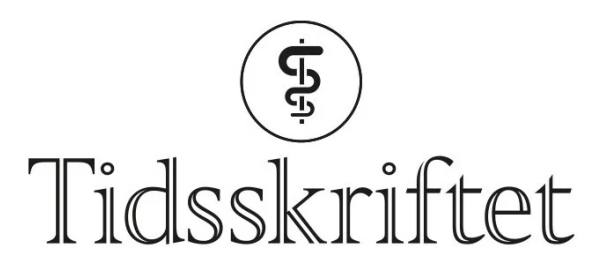

DEN NORSKE LEGEFORENING

\title{
Progestageners terminologi - en presisering
}

KOMMENTAR

\section{GUTTORM RAKNES}

guttorm.raknes@relis.no

Guttorm Raknes er overlege ved RELIS Nord-Norge.

Forfatteren har oppgitt følgende interessekonflikt: Han er forfatter av den opprinnelige artikkelen.

Jeg har av Mette Haase Moen blitt gjort oppmerksom på flere uheldige feil i tabell 1 i min artikkel om progestageners terminologi i Tidsskriftet nr. 9-21 (1). Tabellen er nå rettet i nettversjonen av artikkelen. Inndelingen ble gjort mer på grunnlag av når de ulike progestinene ble utviklet, mer enn den mest vanlige inndelingen i generasjoner.

Det er viktig for meg å få presisert at det er andre generasjon av progestiner (levonorgestrel) som har den laveste dokumenterte tromboserisikoen brukt i kombinasjons-p-piller (2). . Desogestrel (tredje generasjon) har høyere risiko enn det man kunne få inntrykk av tabellen og teksten i artikkelen.

Selv om cyproteron ble utviklet tidlig på 196o-tallet, regnes det ikke som et førstegenerasjonsprogestin, men et antiandrogen med høyere tromboserisiko enn andregenerasjonsprogestiner (므). Etenogestrel (i p-stav) plasseres heller ikke typisk i noen generasjon, men er en aktiv metabolitt av tredjegenerasjonsprogestinet desogestrel (3). Norgestimat plasseres noen ganger i andre, andre ganger i tredje generasjon avhengig av kilde.

Hovedpoenget i artikkelen var terminologien. Progestingenerasjonene og tromboserisiko ble tatt inn som et tilleggsmoment for å belyse kompleksiteten ytterligere. Jeg snublet $\mathrm{i}$ denne og beklager feilen.

\footnotetext{
LITTERATUR

1. Raknes G. Progestageners terminologi. Tidsskr Nor Legeforen 2021; 141. doi: 10.4045/tidsskr.21.0o66. [CrossRef]

2. Dragoman MV, Tepper NK, Fu R et al. A systematic review and meta-analysis of venous thrombosis risk among users of combined oral contraception. Int J Gynaecol Obstet 2018; 141: 287-94. [PubMed] [CrossRef]

3. Grandi G, Cagnacci A, Volpe A. Pharmacokinetic evaluation of desogestrel as a female contraceptive. Expert Opin Drug Metab Toxicol 2014; 10: 1-10. [PubMed][CrossRef]
} 
Publisert: 16. august 2021. Tidsskr Nor Legeforen. DOI:10.4045/tidsskr.21.0527

(C) Tidsskrift for Den norske legeforening 2023. Lastet ned fra tidsskriftet.no 26. april 2023. 